\title{
IT TAKES TWO TO TANGO: AN EMPIRICAL TALE OF DISTRESSED FIRMS AND ASSISTING BANKS
}

\section{Oscar Couwenberg and Abe de Jong}

\begin{tabular}{|l|l|}
\hline \multicolumn{2}{|l|}{ ERIM REPORT SERIES RESEARCH IN MANAGEMENT } \\
\hline ERIM Report Series reference number & ERS-2004-049-F\&A \\
\hline Publication status / version & 2004 \\
\hline Number of pages & 32 \\
\hline Email address corresponding author & a.jong@fbk.eur.nl \\
\hline Address & Erasmus Research Institute of Management (ERIM) \\
& Rotterdam School of Management / Rotterdam School of \\
& Economics \\
& Erasmus Universiteit Rotterdam \\
& PoBox 1738 \\
& 3000 DR Rotterdam, The Netherlands \\
& Phone: \# 31-(0) 10-408 1182 \\
& Fax: $\quad$ \#31-(0) 10-408 9640 \\
& Email: info@erim.eur.nl \\
& Internet: $\quad$ www.erim.eur.nl \\
\hline
\end{tabular}

Bibliographic data and classifications of all the ERIM reports are also available on the ERIM website: www.erim.eur.nl 


\title{
ERASMUS RESEARCH INSTITUTE OF MANAGEMENT
}

\author{
REPORT SERIES \\ RESEARCH IN MANAGEMENT
}

\begin{tabular}{|c|c|c|}
\hline \multicolumn{3}{|c|}{ BIBLIOGRAPHIC DATA AND CLASSIFICATIONS } \\
\hline Abstract & \multicolumn{2}{|c|}{$\begin{array}{l}\text { We study the restructuring process of small and medium-sized firms in financial distress. We } \\
\text { have a unique dataset with firms in the Netherlands that are guided in their restructuring effort } \\
\text { by banks. Part of our dataset consists of firms that successfully restructure their operations and } \\
\text { obligations with the help of their bank. Another part consists of firms that, despite the assistance } \\
\text { of their bank, did not succeed in reorganizing their operations and finances. Our empirical test } \\
\text { predicts success and failure in restructuring. We find that banks guide firms in their restructuring } \\
\text { effort and that their assistance is of crucial importance to the success of the restructuring. } \\
\text { However, some firms do not benefit from this assistance, because firms need to be prepared to } \\
\text { undertake radical operational changes before bank assistance is forthcoming. }\end{array}$} \\
\hline \multirow{4}{*}{$\begin{array}{l}\text { Library of Congress } \\
\text { Classification } \\
\text { (LCC) }\end{array}$} & $5001-6182$ & Business \\
\hline & $5601-5689$ & Accountancy, Bookkeeping \\
\hline & 4001-4280.7 & Finance Management, Business Finance, Corporation Finance \\
\hline & HG $3760+$ & Bankruptcy; finance \\
\hline \multirow{7}{*}{$\begin{array}{l}\text { Journal of Economic } \\
\text { Literature } \\
\text { (JEL) }\end{array}$} & M & Business Administration and Business Economics \\
\hline & M 41 & Accounting \\
\hline & G 3 & Corporate Finance and Governance \\
\hline & G21, & Banks \\
\hline & G33, & Bankruptcy \\
\hline & K22, & Corporation and securities law \\
\hline & K33 & International law \\
\hline \multirow{4}{*}{$\begin{array}{l}\text { European Business Schools } \\
\text { Library Group } \\
\text { (EBSLG) }\end{array}$} & $85 \mathrm{~A}$ & Business General \\
\hline & $225 \mathrm{~A}$ & Accounting General \\
\hline & $220 \mathrm{~A}$ & Financial Management \\
\hline & $220 \mathrm{~K}$ & Banking \\
\hline \multicolumn{3}{|c|}{ Gemeenschappelijke Onderwerpsontsluiting (GOO) } \\
\hline \multirow[t]{4}{*}{ Classification GOO } & 85.00 & Bedrijfskunde, Organisatiekunde: algemeen \\
\hline & 85.25 & Accounting \\
\hline & 85.30 & Financieel management, financiering \\
\hline & 85.30 & Financieel management, financiering \\
\hline \multirow[t]{3}{*}{ Keywords GOO } & \multicolumn{2}{|c|}{ Bedrijfskunde / Bedrijfseconomie } \\
\hline & \multicolumn{2}{|c|}{ Accountancy, financieel management, bedrijfsfinanciering, besliskunde } \\
\hline & \multicolumn{2}{|c|}{ Faillissement, herstructurering, schuldsanering, midden- en kleinbedrijf, banken } \\
\hline Free keywords & \multicolumn{2}{|c|}{ Bankruptcy, debt restructuring, financial distress, reorganization } \\
\hline
\end{tabular}




\title{
IT TAKES TWO TO TANGO: AN EMPIRICAL TALE OF DISTRESSED FIRMS AND ASSISTING BANKS
}

\author{
Oscar Couwenberg \\ University of Groningen \\ o.couwenberg@rechten.rug.nl \\ Abe de Jong \\ Erasmus University Rotterdam \\ a.jong@fbk.eur.nl
}

Current Draft: June 17, 2004

Keywords: bankruptcy, debt restructuring, financial distress, reorganization JEL Classification Numbers: G21, G33, K22, K33

Correspondence to: Oscar Couwenberg, University of Groningen, Faculty of Law, Department of Law and Economics, P.O. Box 716, 9700 AS, Groningen, The Netherlands. We express thanks to Anton Duizendstraal, N.E. Dennis Faber and S. (Bas) C.J.J. Kortmann for comments on earlier phases of this research. The empirical of this research has been conducted when Couwenberg was a researcher to the Institute Firm and Law of the Catholic University of Nijmegen. 


\title{
IT TAKES TWO TO TANGO: AN EMPIRICAL TALE OF DISTRESSED FIRMS AND ASSISTING BANKS
}

\begin{abstract}
We study the restructuring process of small and medium-sized firms in financial distress. We have a unique dataset with firms in the Netherlands that are guided in their restructuring effort by banks. Part of our dataset consists of firms that successfully restructure their operations and obligations with the help of their bank. Another part consists of firms that, despite the assistance of their bank, did not succeed in reorganizing their operations and finances. Our empirical test predicts success and failure in restructuring. We find that banks guide firms in their restructuring effort and that their assistance is of crucial importance to the success of the restructuring. However, some firms do not benefit from this assistance, because firms need to be prepared to undertake radical operational changes before bank assistance is forthcoming.
\end{abstract}




\section{Introduction}

Situations of financial distress have a major impact on a firm and on its stakeholders. In order to prevent further wealth-dissipation, the firm's managers need to undertake substantial corrective action. This corrective action can be taken informally, where, among others, firms aim to renegotiate the terms of debt contracts with creditors without using a bankruptcy procedure. A second possibility for the firm's management or its creditors is to petition for bankruptcy, in which the process of restructuring is partially defined by legal procedures. It is obvious that the expected behavior of a firm and its creditors in the formal procedure has a strong impact on the incentives of both parties to reach an informal agreement. In harsh bankruptcy systems the possibility to reorganize is limited. This implies that the pressure on informal reorganization is high, because of the threat of liquidation. In soft systems reorganizations are part of the formal procedure, which limits the incentive to strive for a settlement outside the procedure. An important issue in the law and economics literature is the efficiency of bankruptcy systems. In this paper we provide empirical evidence on informal reorganizations under a harsh regime.

Bankruptcy systems and legal procedures differ between countries. Most studies of firms in bankruptcy concern the United States (U.S.), which has a soft debtor-oriented, system. Its reorganization procedure, Chapter 11, shields the firm from its creditors. A harsh creditor-oriented system prevails in the United Kingdom (U.K.) and its main objective is the repayment of creditors' claims (Franks and Torous, 1996). ${ }^{1}$ Most other systems, either resemble the U.S. or the U.K. system, or mix these two extremes. For example, in Germany and France relatively new systems have been implemented that are less harsh than the U.K. system, but not so debtor friendly as Chapter 11 in the U.S. (White, 1996; Kaiser, 1996; Couwenberg, 2001). In Japan, a procedure similar to Chapter 11 exists, extended with a screening of cases for viability (Eisenberg and Tagashira, 1994). Our analysis concerns distressed firms in the Netherlands where Dutch firms face a harsh bankruptcy system. The institutional setting makes only two outcomes of a restructuring process possible: firms restructure successfully and stave off bankruptcy, or firms end up in the formal bankruptcy

$1 \quad$ Although the recently enacted Enterprise Act 2002 may change this. It imposes the duty upon the administrator to attempt a business rescue if this is in the interest of creditors. It also limits the possibilities of secured creditors to control the bankruptcy process. See http://www.insolvency.gov.uk/. 
procedure. Because the Dutch setting - together with the U.K. system - is on the other side of the continuum with the often-studied U.S. firms, our study provides an interesting experiment of the value of a harsh system in reorganizations.

We study the process of restructuring in financially distressed small to medium sized Dutch enterprises. Our sample is unique in that it contains small and medium sized, non-quoted, firms that are successful in their restructuring efforts and firms that are not. We are able to compare their characteristics and identify the factors that contribute to their success, or failure, in restructuring the business. For the firms in our sample, banks play a crucial role in covering their financing needs and thus, presumably, also play an important role in resolving financial distress. Our study resembles the one by Franks and Sussman (2003). They study financial distress and bank debt restructuring of small and medium sized enterprises in the U.K. Franks and Sussman find that the contingent control rights associated with legal security rights put banks in nearly full control over the firm in the event of default. Banks make very limited concessions, but cannot be characterized as lazy in their efforts.

Our sample consists of 73 firms that were monitored by their main banks. Out of this sample, 51 firms (69.9\%) restructured successfully, while 22 firms (30.1\%) failed and went bankrupt. We study the characteristics before reorganization, the measures taken in the process of reorganization, and we discriminate between factors that do or do not distinguish success from failure. Our main findings are that banks appear to be informed about the pre-distress indebtedness and choose to restrict their lending to high-risk firms. The analysis of the restructuring measures shows that many firms take operational measures and effectuate measures that banks advice, together with measures related to restructuring the bank's debt. We find that the success of restructuring efforts depends mainly on operational measures that are induced by banks. We conclude that banks are co-operative, but only in case firms are prepared to take corrective actions. Our findings illustrate that under the Dutch harsh rules the threat of bankruptcy is present and that restructurings are often successful. However, the success of restructuring is not simply dependent on the bankruptcy threat. Both the firm's management and the main bank have to agree on the restructuring plan, i.e. "it takes two to tango".

The paper is structured as follows. In section 2 we describe the institutional characteristics of the Dutch setting and discuss the different incentives that can be discerned in a financial distress situation. In section 3 we describe our dataset. Section 
4 presents our results. Section 5 summarizes the empirical results and relates the findings to the theoretical discussion. Section 6 concludes.

\section{Restructuring small firms in financial distress}

In this section we discuss the Dutch institutional setting and the current literature. We first summarize the Dutch bankruptcy system in order to understand the influence it has on the incentives to restructure privately (2.1). Subsequently, we describe the practice of banks in assisting failing firms (2.2). We discuss the theoretical views on the incentives in restructuring processes and the related empirical evidence (2.3). Finally, we discuss the specifics of small firms (2.4) and conclude (2.5).

\subsection{The Dutch bankruptcy system}

The Dutch bankruptcy system can be characterized as an auctioning system, with a rudimentary reorganization provision (Couwenberg, 2001). As such it is very similar to the Swedish system (see Thorburn, 1999) and the pre-1993 Finnish procedures (see Sundgren, 1998). Within the bankruptcy system a suspension of payments procedure is included, which aims at firms in financial distress and with sufficient prospects to recover in short time. The suspension procedure applies only to ordinary creditors and suspends all individual debt collection procedures. Secured and preferred creditors are not bound by this procedure. As a result, write-downs on the secured and preferred claims by these creditors are voluntarily. Part of the suspension procedure is that the firm has to offer a settlement to the ordinary creditors (others than secured and preferred creditors). The procedure ends in case the creditors accept the terms of the settlement. In comparison with the bankruptcy procedure, the suspension procedure is less intrusive in the operational decision-making and in the rules by which creditors are bound. When the settlement in the suspension procedure fails, firms cannot opt again for this procedure. Moreover, firms cannot then opt for the near identical settlement procedure in bankruptcy.

For firms that do not use the suspension of payment procedure, only the bankruptcy procedure remains. Both firms and creditors may petition for bankruptcy. At the start of the bankruptcy proceedings an independent trustee, appointed by the 
court, replaces the incumbent management team. This trustee has a fiduciary responsibility to all creditors. The procedure offers the trustee the possibility to continue operations. The firm is sheltered from its creditors by an automatic stay provision of up to two months. The firm can attract estate-financing with superpriority. The trustee organizes a sale of all assets, either piecemeal or as a going concern. This sale may take the form of a private sale of assets or a public auction. The proceeds of this sale are distributed according to absolute priority. Administrative costs, estate-financing and taxes accrued during the period of continuation in bankruptcy have super-priority. Secured claims are entitled to receive the proceeds of the sale of the collateral, while any unpaid part is treated as an unsecured claim. Next in line are audit claims, tax claims, wage claims, and finally, unsecured claims.

In the Netherlands, despite the facilities in a suspension of payments, almost all suspensions end in formal bankruptcy proceedings. Apparently, the procedure is ineffective in reorganizing firms. A key reason for the ineffectiveness is that the procedure only applies to ordinary creditors. Furthermore, buyers of assets from firms in a suspension procedure have to accept all employee contracts associated with the assets. This is not the case in bankruptcy. Therefore, the reorganization of firms via the asset sale is normally postponed until the firm enters the bankruptcy procedure (Couwenberg, 1997).

From this description of the Dutch legal and institutional setting it becomes evident that when firms desire to continue their activities in their present form, it is paramount to stay out of bankruptcy proceedings. Although bankruptcy does not have to lead to the demise of the firm, it leads in many instances to a loss of control - and the associated benefits thereof - and to a diminished scale of activities.

\subsection{Dutch banks}

Banks in the Netherlands have specialized departments, i.e. work-out departments, which deal with firms in financial distress. ${ }^{2}$ These offices are hierarchically organized. The smallest firms in distress remain under the surveillance of local offices. The small to medium sized debtors in financial distress are transferred from local offices to headquarter-based work-out departments. The departments are enlisted when the loan

2 These departments have euphemistic names, such as 'special loans' (bijzondere kredieten). The departments also have nicknames that plainly indicate their activities, e.g. ABN-AMRO’s special 
size passes a size-threshold and (combinations of) additional criteria are met, e.g. firms do not meet debt covenants, profitability is too low, or equity is insufficient. Specialized employees in these work-out departments deal with the largest and exchange-listed firms in financial distress. All the firms in our study have been assisted by bank employees of the work-out departments located at the headquarters of Dutch banks. The employees of work-out departments take over the tasks of local offices with respect to these firms. They advise firms on restructuring activities and propose debt restructuring arrangements. These latter arrangements have to be approved by internal credit committees in the bank. When distressed firms do not manage to renegotiate with the bank and to restructure, the bank will strive to end the financing relationship with the firm.

\subsection{Literature on banks and restructuring}

A key question in debt restructuring processes concerns the behavior of banks. Restructuring situations confront banks with a multitude of incentives. These incentives are associated with security arrangements, the costs of monitoring, anticipated strategic behavior by entrepreneurs, and bankruptcy rules.

\section{Security arrangements}

Security by means of collateral may lead to a lazy attitude of the bank, which implies that too little effort will be expended to help firms restructure. ${ }^{3}$ Banks do not need to undertake corrective actions, as long as the value of the assets securing a loan exceeds this bank debt. Corrective actions can be fairly egoistic, i.e. solely focused on the value of the bank debt. For example, banks can demand partial repayment, lower credit ceilings, and demand additional collateral. However, this lazy attitude is in contradiction with the advantageous position of the bank concerning the quality and timeliness of information. Banks are better informed and equipped than other creditors to monitor borrowers and may thus be expected to react timely to adverse economic developments. Thus, banks' laziness is not optimal from a firm's

loan department is called ‘the wreck station' (de wrakkencentrale). See NRC Handelsblad of June 5, 2003.

3 Laziness may be the result of a risk-return trade off. Senior/secured creditors have an incentive to opt for low risk liquidation in stead of high risk continuation via new financing (Myers, 1977). Manove, Padilla and Pagano (2001) develop another argument tot explain laziness. In their model wellsecured banks underinvest in project screening activities. They suggest that laziness is one of the prime elements in the argument to limit the possibility to contract for collateral. 
perspective. The lazy attitude of banks may diminish when bank debt is junior in the debt hierarchy. Bank claims will then be at risk in a relatively early stage of financial distress. However, this solution also generates problems. Concentrated, wellinformed, but junior bank-creditors may collide with the owner in an effort to keep an inefficient firm alive, at the cost of senior/secured dispersed public debt holders (Bulow and Shoven, 1978 and more recently Bigus, 2002). Couwenberg and Helmantel (2004) show that the alternative collateral arrangement - the allocation of collateral to the well-informed bank-creditor - mitigates this coalition behavior. ${ }^{4}$

\section{Monitoring costs}

In financial intermediation theory banks function as delegated monitors (Diamond, 1984; Haubrich, 1989). Bank monitoring is more efficient than monitoring by a multitude of investors. However, banks have an incentive to minimize monitoring costs. Monitoring effort and costs are lower when banks are the senior and/or the secured lenders. Cost-efficient monitoring and security thus go together, which strengthens the incentive to be lazy. Udell (1989) argues that separate loan review departments in banks are not necessary as a monitoring device aimed at borrowers. A separation is needed to mitigate conflicts of interests that arise in the relations between loan officers and borrowers. He provides some evidence to support this limited monitoring effort by banks.

\section{Strategic behavior}

In an incomplete financial contracting setting, secured debt arises due to the possibility of strategic asset deployment by the entrepreneur or claim dilution (Gorton and Kahn, 1993; Hart, 1995; Hart and Moore, 1998). Controlling for this strategic behavior requires secured debt, because it gives credence to the threat to take the assets from the entrepreneur. The upshot is, again, that it is efficient that banks hold collateral. However, the bank remains vulnerable to expropriation up to the level of the liquidation value of the assets. Bolton and Scharfstein (1996), Berglof and Von Thadden (1994) and Berglof, Roland and Von Thadden (1999) show that dispersing debt among many creditors disciplines management and reduces opportunistic

\footnotetext{
$4 \quad$ Welch (1997) provides an additional perspective. He argues that banks, as concentrated debtholders, should have strong seniority rights, because this minimizes ex post haggling costs. Therefore, it is cost efficient to concentrate seniority rights.
} 
behavior. The collective action problem, which is raised by dispersing debt, deters strategic renegotiation. Franks and Sussman (2003) test for this "soft bank" effect. The authors indeed find that strategic renegotiation by the borrower forces the bank to give in, while trade creditors hold out on any restructuring effort.

\section{Bankruptcy rules}

Each country has its own set of bankruptcy rules. These rules may either exacerbate or facilitate the process of restructuring. It is a stylized fact that banks hold the collateral. ${ }^{5}$ Thus, an interesting question is how distressed firms restructure and what the role of banks is in this process. Theoretical research shows that this role depends on the interaction between debt structure and bankruptcy rules (see Bulow and Shoven, 1978; White, 1980; and Diamond, 1993). Harsh bankruptcy rules, i.e. rules that do not incorporate the possibility of reorganization, imply that reorganization needs to be done privately. Firms and banks are forced to renegotiate in order to prevent the difference in value to be lost. Such rules may partly counteract the laziness associated with secured credit. Softer bankruptcy rules, with reorganization provisions, as in Chapter 11, on the other hand provide firms and debt holders a (costly) procedure to eliminate collective action problems associated with public debt. From these models it follows that concentrated (bank) debt will be senior and secured and shorter in maturity than public debt (see Diamond, 1993; and John and Vasudevan, 1995). Nevertheless, Gertner and Scharfstein (1990) argue that investment inefficiencies will remain.

\section{Empirical evidence}

Asquith, Gertner and Scharfstein (1994) study financially distressed junk bond issuers. They find that banks do not forgive principal payments outside Chapter 11 and only rarely take equity. ${ }^{6}$ Furthermore, the provision of additional financing to these firms occurs only in Chapter 11 procedures. Gilson (1990), on the other hand, finds that in debt restructurings and Chapter 11 reorganization plans, banks do receive stock. Covenants in bank lending agreements also change: banks claim (additional) collateral and veto power over investment and financing decisions. Franks and Torous

\footnotetext{
5 See, e.g., Franks and Sussman (2003).

$6 \quad$ In line with this is the paper by Bergstrom, Eisenberg and Sundgren (2002). They find that in Finland well-secured creditors are most likely to oppose reorganizations.
} 
(1994) compare out-of-court restructurings with Chapter 11 reorganizations and find that the latter firms are less solvent, have lower recovery rates, but smaller deviations from the absolute priority rule, and use more cash as form of repayment to creditors than in out-of-court restructurings. James (1995) finds that only when public debt holders restructure their claims, banks are willing to take (a relatively large stake of) equity. Gilson, John and Lang (1990) study a sample of troubled debt restructurings. Their sample comprises successful and unsuccessful debt restructurings, i.e. Chapter 11 filings. Private renegotiation is most likely to succeed when more of the assets of the firm are intangible, more debt is owed to the bank and the debt structure is relatively simple.

\subsection{Distress in small firms}

For small firms, the role of banks must be - out of necessity - even more important than the research on large firms and Chapter 11 reorganizations reveal. Shareholders of the firm are most likely cash-constrained, because otherwise the firm would not be in financial distress. Up till distress, banks are not particularly focused on the performance of borrowers, due to monitoring costs and liquidation rights associated with the possession of collateral. Due to the illiquid markets for small firm equity stakes and regulatory capital requirements, banks are not very interested in becoming shareholders of small firms. Without the upside potential associated with a successful restructuring, banks have limited incentives to assist small distressed firms to recover. One may argue that trade creditors in small firms play the same role of public, dispersed debt holders in large quoted firms, Thus small firms may be confronted with the same behavior of banks as large firms are confronted with. However, small nonquoted firms do not have many options besides talking to their bank. Trade creditors might be unwilling to extend credit, due to increasing day's payable, because of a lack of information and free riding by the others. In such instances the only option open to firms is to turn to their bank. It means that the banks' incentives and the needs of firms are unaligned to each other. This could lead to the situation that banks are lazy in their help to restructure firms.

The only large-scale empirical evidence about restructuring efforts of small firms is Franks and Sussman (2003). They find for small U.K. firms that banks do not 
forgive or scale down principal payments and only rarely provide additional financing, but frequently succeed in reducing their outstanding loans. In their sample the additional financing comes from trade creditors. In this manner the banks in their sample are tough, even though the U.K. does not seem to have any soft bankruptcy rules to counteract the tendency to overliquidate.

\subsection{Conclusion}

The allocation of collateral to a bank saves monitoring costs, diminishes the risk of overcontinuation and deters strategic behavior by entrepreneurs. A stylized fact is that banks (nearly) always obtain the available collateral, especially in small firms, or in larger firms provide the senior debt. The problem of underinvestment by banks in distressed firms is counteracted by harsh bankruptcy rules. Private renegotiation then needs to prevent the loss of firm value in bankruptcy. In the case that a renegotiation chapter exists in bankruptcy rules, banks need not portray that measure of responsiveness to distressed firms. The burden of the debt restructuring then falls in first instance on ordinary and junior debt holders.

The Dutch setting is characterized by harsh bankruptcy rules. This implies that a debt restructuring needs to be organized privately. This paper provides empirical evidence on whether this occurs in the practice, what measures are used and the characteristics of successful firms.

\section{Data}

The dataset in this study consists of Dutch firms that encountered financial distress and received assistance from banks. Part of the firms in our sample managed to restructure successfully, while others failed. We obtained files about bank assistance of restructuring firms directly from banks. The data in this study is provided by the three largest banks in the Netherlands, i.e. ABN-AMRO, ING Bank and Rabobank. All firms in our samples have been assisted by employees of the work-out departments of the banks' headquarters. The banks were prepared to fully disclose their files on the financially distressed firms. These files contain financial information, such as income statements and balance sheets. The bank's files also contain detailed 
information about the restructuring measures by the bank, but also by other parties. The restructuring processes in our sample cover the period from 1981 until 2000. The sample is more or less evenly spread out over these years.

Our sample of successfully restructured firms is based on the following procedure. We obtained lists of distressed firms from the three banks. All firms that eventually ended up in bankruptcy or suspension of payment were removed from the list. ${ }^{7}$ Because the resulting list still was too long to cover completely, we picked per bank 20 to 30 cases and asked the banks to retrieve these files. Not all files were retrievable anymore and some were incomplete. Ultimately, we retrieved 51 files of firms in financial distress. ${ }^{8}$ Our sample of bankrupt firms has been selected in another way. This list was build from bankruptcy filing records of different regional court jurisdictions in the Netherlands. Based upon this list the appointed trustees, associated with law firms, were asked to provide case details. In this project 139 bankrupt firms have been included. The names and addresses of these 139 firms were matched with the names and addressed in the banks' databases. This procedure yielded 22 firms on which enough data was available on the restructuring phase before these firms filed for bankruptcy. ${ }^{9}$ In total we have 73 firms of which 51 (70\%) restructured successfully and of which 22 (30\%) were not successful in their restructuring attempts and thus had to file for bankruptcy.

It should be clear from the outset that our sample has a selection bias. All firms have been under surveillance by banks. This implies that our outcomes are conditional on bank involvement in the process of restructuring. Firms also become distressed and solve their problems without involvement by banks, or firms initiate bankruptcy proceedings without prior assistance by banks. These firms do not enter our sample selection procedure.

$7 \quad$ This does not guarantee that a firm on our list never entered bankruptcy proceedings. However, firms were not involved in bankruptcy while the bank was supplying any form of financing. If the firm changed banks, or was taken over, then the information on future performance was obviously not available.

8 We were not able to retrieve consistent time-series data on the firms, due to the fact that in nearly all the successful cases the borrower returned to the local branch and it proved too much effort and time to reclaim the files. In other instances change of bank and take-overs prevented us from collecting end of period data. 


\section{Results}

The dataset consists of two samples. The first set includes 51 "successful firms", i.e. firms that restructured under the guidance of a bank and managed to stay out of formal bankruptcy proceedings. The second set includes 22 “unsuccessful firms”, i.e. those that ended in bankruptcy despite the banks' assistance. In this section we first describe the size and activities of successful firms and their unsuccessful peers in order to test whether the groups are comparable (4.1). Subsequently, we describe the reasons of the distress and the outcomes of the restructuring processes (4.2). Both for the successful and unsuccessful firms we provide the firm characteristics (4.3) and the measures taken in the restructuring process (4.4). Finally, we present a set of logit regressions explaining the differences between the two sets of firms (4.5).

\subsection{Comparison of the samples}

We compare the two samples in order to test whether both groups contain comparable firms. The results are presented in Table 1. We construct four size groups. The smallest firms have total assets below 1 million Dutch guilders, while the largest firms have assets of over NLG 10 million. $^{10}$

\section{[Insert Table 1 here]}

The results in Panel A of Table 1 indicate that in terms of size the firms in the two samples are comparable. In the group of successful firms the larger firms are slightly over-represented (65\% of the sample) in comparison with the unsuccessful group (41\%), but this difference is too small to bias our results. In Panel B we distinguish 5 industries. In both samples, most firms are in the manufacturing industry. However, relatively more unsuccessful firms are in this industry. The results in Panels A and B indicate that although some differences exist, the two groups of firms are comparable in terms of size and activities.

$9 \quad$ The reasons for this low retrieval rate are: i) cases were too small for the work-out department; ii) firms may have run into trouble so fast that assistance was not an option anymore; iii) frequently, name and addresses simply did not match.

$10 \quad$ One Dutch guilder (NLG) equals approximately 0.454 Euros. 


\subsection{Reasons for distress and outcomes of the restructuring processes}

In Panel C of Table 1 we present the reasons for the firms' distress. In both samples, $59 \%$ of the firms indicate that market forces are a main reason for the distress. This is an external factor. Another external reason is "restrictive contracts", which is less important, i.e. $6 \%$ and 5\%, respectively. All other causes are internal problems. The second main reason is, in both samples, the cost level. Other important factors are overinvestment (although more so in the successful group than in the unsuccessful group) and weak management. Note that, with respect to these reasons, there is a large similarity between the two samples.

Panel D of Table 1 explains how the restructuring ends. For the group of successful restructurings the following resolutions can - ultimately - be discerned: restructured (37\%), not restructured but "successfully" turned around (4\%), restructured and repayment of loans through new financier (33\%), restructured and taken over (25\%). In the first two outcomes the firm keeps its relationship with the assisting bank, while with the latter two the firm - as a customer - leaves the assisting bank. The group of unsuccessful firms ends up in bankruptcy. In bankruptcy they may sell assets in a going concern sale (64\%), liquidate piece-meal (32\%), or complete a bankruptcy composition (5\%).

\subsection{Firm characteristics}

Table 2 presents the financial characteristics of the firms in the last available book year before the restructuring. As in the previous table, it shows that firm size does not differ significantly between the two samples. The average size of successful firms is NLG 25.4 million, while unsuccessful firms have mean size of 14.4 million. The difference of 11 million has a $t$-value of 1.60 , which is not significant at the $10 \%$ level.

The indebtedness, however, differs strongly between successful and unsuccessful firms. Firms that manage to stay out of bankruptcy have an 89.6\% debt ratio, defined as debt relative to the total (book) asset value. For the bankrupt firms this percentage is $134.3 \%$, which implies that the nominal debts are larger than the book value of the assets. In other words, these firms have on average a negative book value of equity. 
The structure of the debt also differs between the two groups of firms. Successful firms have significantly less short-term debt, i.e. $36.0 \%$ versus $51.0 \%$. This result implies that the short-term claims threaten the success of a restructuring. The inverse is found for interest-bearing debt. It should be noted that much of the short term debts are not interest-bearing and thus a negative correlation between these two variables exists.

The amount of bank debt divided by total debt differs between the two groups. Unsuccessful firms have 39.8\% bank debt, while their successful peers have 55.1\%. The difference is significantly different from zero at the $1 \%$ significance level. This result implies that banks provide a smaller portion of total debt to unsuccessful firms. We also have information on the collateral that banks have obtained. For purposes of this study, we distinguish five types of collateral. Firms may provide banks a mortgage on real estate, they may pledge tangible fixed and current assets, pledge receivables, acquire equipment via a lease contract, and the firm owners may personally guarantee debts. ${ }^{12}$ In both groups, the number of collaterals that firms have pledged out of the set of five is similar, about three. Finally, we compare the nominal value of the collateral with the nominal bank debt. If the collateral, when repossessed and sold, should yield the nominal value, a ratio of collateral value and bank debt of 1 is sufficient to recover all of the bank debt. In our successful restructuring sample the collateral is 2.046 times the bank debt, while in the unsuccessful sample the ratio is 2.338. The finding that bank debt is on average about half of the total assets and the collateral is twice the bank debt implies that on average banks have the entire total assets as collateral.

The average length of the restructuring period is approximately 24 months in both samples. In comparison, Franks and Sussman (2003) find for small U.K. firms an average of 9.2 months for firms that restructure successfully and 5.2 months for firms that end in bankruptcy proceedings. These results show that the Dutch restructuring processes take much longer. Remarkably, our findings are more in line with the period that U.S. firms stay in Chapter 11 procedures (see Gilson, John and Lang, 1990; Franks and Torous, 1994).

11 This implies that no restructuring activities were undertaken, but that the operational results improved to such an extent that assistance was not longer indicated.

12 In the Netherlands there is no security in the form of the floating charge, as in the U.K. 
Our descriptive statistics lead to two conclusions. First, banks are able to discriminate between successful and unsuccessful firms before the restructuring starts. Banks have relatively less debt in unsuccessful firms, in comparison with other providers of debt. Moreover, banks have obtained more collateral in firms that turn out to be unsuccessful. This gives some credence to the observation that banks are able to anticipate bankruptcy, because banks predict bankruptcy better than other debt holders. The second conclusion is that bank debt seems to be "over-collateralized". Of course, the book value of collateralized assets is likely to overstate the value in case of distress and bankruptcy. Research on the firm recovery rates in other countries shows that bankruptcies of small firms on average yield $35 \%$ to $45 \%$ of the total nominal debt value (Thorburn, 1999; Ravid and Sundgren, 1998; Sundgren, 1998; Franks, Nyborg and Torous, 1996). ${ }^{13}$ This implies that a large fraction of the book value of assets is lost in bankruptcy. The available evidence on recovery rates in bankruptcy proceedings with respect to secured credit shows that these are much higher than firm recovery rates, but on average do not reach the $100 \%$ ratio. Franks and Torous (1994) report an average percentage of 80\%, Thorburn (1999) finds 69\% for secured debt and Franks and Sussman (2003) 74\% to $77 \% .{ }^{14}$ Over-collateralization seems therefore to be necessary in order to secure debt in any meaningful way.

\subsection{Restructuring measures}

Table 3 describes which measures are taken in the distressed firms. We distinguish seven categories of measures, dependent on which party initiates the measure and the characteristics of the measures: financial measures by the shareholders, banks, and non-bank creditors (Panel A-C), operational measures by the firm (Panel D), governance by shareholders and the board (Panel E-F), and management leaving the firm voluntarily (Panel G). With the information available it was not always possible to pinpoint the exact measure taken, although documents revealed that a measure in a specific category was chosen. Therefore, the "Total” score also comprises these observations, while the detailed measures are only included if specific evidence was found.

13 If measured on total book value basis, recovery rates are somewhat, but not spectacularly, higher. See Sundgren (1998). 


\section{Financial measures}

Panel A shows that 3.9\% of the successful firms received additional equity from the shareholders, while in the unsuccessful firms the corresponding percentage is $13.6 \%$. The $p$-values are the result of a difference test, which estimates whether the probability that a measure is taken is not significantly different between the two samples. The $p$-value is $14 \%$, which implies that the difference is not significant at the $10 \%$ level or less. As the data in the panel shows, shareholders do contribute new funds (either equity or debt) in approximately $20 \%$ of the cases and this finding is more or less the same in both groups. This lack of funding activities by shareholders is in conjecture with debt overhang problems and/or wealth constraints. Clearly, the role of shareholders does not make the difference between success and failure.

Panel B shows the changes in firms' financing provided by the bank. The total score beneath the panel indicates that in $90 \%$ of the successful firms, banks assisted by changing conditions. This is statistically significantly more at the $5 \%$ level than in the other group (59\%). In other words, if banks induce more measures, the probability of survival increases. It is remarkable that extension of interest payments, reduction in interest rate, and an easing of credit conditions never or nearly never occur in both groups. We also find that debt write-downs never occur, which implies that banks do not help firms via a scale-down of their own positions. The extension of principal repayments occurs relatively frequently in both groups, although more so in the successful group (33\% versus 23\%). On the other side, banks also hasten repayments (33\% versus 18\%), but demand additional collateral only in the successful group (43\% versus $5 \%$ ). This latter difference is statistically significant at $1 \%$. This is a curious finding because in both groups banks hold similar levels of collateral. The finding may be explained by the fact that the demand of additional collateral, when bankruptcy is imminent, may be considered as fraudulent behavior by the trustee. This presupposes though that banks are capable of an ex ante screening of the successful firms from the unsuccessful firms. Additional debt under (new) conditions is forthcoming in more than half of the cases in both groups (59\%). Although additional debt is provided to the same fractions in each group, the conditions differ. We find four conditions that are significantly more often negotiated with successful firms: additional restrictive covenants (77\% versus $32 \%$; difference is significant on $1 \%$

14 Tashijan, Lease and McConnell (1996) find recovery rates of nearly $100 \%$ for secured 
level), additional information (57\% versus 27\%; difference is significant on $5 \%$ level), divestments of assets (37\% versus 5\%; difference is significant on $1 \%$ level), reinforcement of management (31\% versus 9\%; difference is significant on 5\% level). The two other conditions are that new equity or junior debt is forthcoming from shareholders or other groups (14\% versus 23\%) and additional collateral (45\% versus $36 \%$ ). Thus, the successful group differs significantly from the unsuccessful group on four out of six conditions. The overall result for banks indicate that $90 \%$ of the successful firms are aided by banks, while only $59 \%$ of the unsuccessful firms receive assistance. The role of banks in resolving financial distress is thus more extensive in successful firms than it is in unsuccessful firms. Of course, the causation cannot be defined based upon this table. This difference in the role of banks may be due to the attitude of the firms, i.e. whether management is co-operative or not.

Panel C shows the role of non-bank creditors in the restructuring of the firm. Among the various measures no significant differences between the two groups occur. With respect to the occurrence of the measures two stand out: additional funds (22\% versus $27 \%$ ) and extension of trade credit (18\% both). Presumably, other creditors are sometimes prepared to keep a customer afloat, either by way of extension of credit or even additional funds.

The overview of financial measures yields interesting conclusions with respect to the involvement of banks. Banks are not "lazy" in general but selective. In successful restructurings banks are more involved than other debt holders, while nearly the inverse holds for unsuccessful firms. This result has two potential reasons. On the one hand banks may focus their effort on viable firms and provide help to successful firms, i.e. they discriminate effectively. On the other hand the help of banks may be the key to success and firms are rescued because banks help them out. Of course, if firms are successful, partly due to the involvement of banks, the other creditors also benefit. Inasmuch their efforts are not needed, or only auxiliary to the success they can be considered as having a free ride on the efforts of banks.

\section{Operational measures}

Panel D shows the operational measures taken in both groups of firms. They differ significantly (1\% level) with respect to their total score. In the group of successful 
firms more firms take operational measures than in the unsuccessful group (86\% versus 50\%). Especially striking is the difference in the measure sell assets: $57 \%$ versus $9 \%$ (significant on $1 \%$ level), which seems to drive to overall difference. The other measures have more or less similar scores in both groups. Furthermore, it seems that some measures are more popular than others: Changing strategy, reorganizing production, stepping up financial controls, rescue via take over and reducing the work force. These measures are taken in approximately a quarter of the cases in both groups, while the other measures are below 15\%. Although successful firms take more operational measures than unsuccessful firms, the scores seem fairly low, given the fact that the firms are all (severely) distressed.

\section{Governance measures}

Data on the role of shareholders is provided in Panel E of Table 3. In the group of successful firms shareholders act more often, than in the unsuccessful group. And this difference is statistically significant at $1 \%$ level (51\% versus $27 \%$ ). The data for unsuccessful firms was in many instances not specific enough to be attributed to individual measures, which explains why such a result is not present for individual measures. An exception is the replacement of management, but few observations are involved in this measure. The role of the board of supervisors in Panel $\mathrm{F}$ is even less pronounced. No differences between the groups occur and the frequencies of activities are fairly low. Finally, Panel G reports that management resigns voluntarily in 15.7\% and $18.2 \%$ of the firms, respectively. The difference between the two groups is insignificant and the incidence is also fairly low. Given the characteristics of small firms, it is not so much of a surprise to find shareholders to be more active than the board. Small firms either do not have boards to monitor and control management, or boards play a different role, e.g. providing specific knowledge, giving access to a network of relations and maybe even image-building.

Panel $\mathrm{H}$ reports the average number of measures taken and the fraction. In measures taken (absolute and fraction) the successful group differs significantly on $5 \%$ level from the unsuccessful group (9 versus 6 measures, or 20\% versus 14\% fraction).

\subsection{Predicting the success of restructuring}


In the previous analyses we have documented several differences between successful and unsuccessful firms in uni-variate comparisons. An interesting issue is whether success can be predicted. We perform logit regressions, which explain the probability of success, and thus the differences between successful and unsuccessful firms in a multi-variate setting. A major advantage of the multi-variate framework is that we can control for factors as size and indebtedness. The results are reported in Table 4 and Panel A contains firm characteristics, while Panel B has the restructuring characteristics.

Regression (1) contains control variables for size and industry. We include a log-scaled measure of total assets and three dummy variables for industries. The two remaining industries are excluded, because few firms are in these groups and in order to avoid multi-collinearity. The results show that size is insignificant, with a z-value of 1.52. The dummy manufacturing is significantly negative at the $10 \%$ level, which indicates that manufacturers are less likely to be successful in restructuring. Finally, regression (1) includes the relative amount of debt. The coefficient is negative and significant at the $1 \%$ level. Clearly, higher debts before restructuring reduce the probability of survival. McFadden's $R^{2}$ is the standard measure for the explanatory power of a logit regression and a value of 0.351 is acceptable.

In order to test whether the effect of debt is driven by short-term debt, by interest-bearing debt or by bank debt, we add these characteristics and remove overall debt in regressions (2), (3) and (4). The significantly negative result for short-term debt in regression (2) shows that debt maturity has a positive effect on survival chances. On the other hand, as described in regression (3), interest-bearing debt does not affect the success of the restructuring. In regression (4) we investigate the role of banks and include bank debt and collateral. Bank debt has a significant positive effect, which indicates that more bank debt in the total debt structure increases the probability of success. Apparently, bank debt differs from other forms of debt. This result is in line with the uni-variate results. The number and value of collaterals before restructuring do not significantly affect the probability of survival.

Bank debt has a correlation of -0.39 with total debt. In unreported additional regressions we include both the debt ratio and the relative amount of bank debt. We find that bank debt turns insignificant, which indicates that the total debt effect dominates the bank debt effect. The importance of total debt is also illustrated by the high $R^{2}$ in equation (1). 
In Panel A, we include the characteristics describing the firm before restructuring, while in Panel B we add the restructuring activities. First, in regression (5) we include the fraction of measures. The resulting coefficient is positive, suggesting that more activities are better. However, the coefficient is insignificant. Unreported additional tests show that the number of months also has no significant effect (the coefficient is -0.01 with a $z$-statistic of -0.86 ).

Next, in regression (6) we include the total scores for each of the seven categories in Table 3. The results confirm our earlier results. Banks have a positive impact, significant at the $1 \%$ level. Other creditors exhibit a negative coefficient, significant at the 5\% level. All other measures yield insignificant coefficients. This contrasts with some of the uni-variate results. Table 3 shows that, in contrast with our multi-variate result, the score on other creditors does not differ significantly between the two groups. For operational activities, the uni-variate results led to a highly significant difference. But this result is lost in regression (6). To find out why this happens we specify two additional regressions.

Regressions (7) and (8) include several individual specific measures in order to learn about the influence of banks. In the discussion on the role of banks, significant uni-variate differences were found on the conditions that were attached to the provision of additional debt. In regression (7) we included a dummy for banks that induce firms to divest. We also included divestment in general, minus bank-induced divestments. Thus, the latter variable measures all divestments that are not "forced" by banks. The result clearly shows that divestments have their positive effect only in the case that banks attach divestments as a condition for the provision of additional debt. The three other individual measures as conditioned upon additional debt also improve the chances of survival. Regression (7) yields the result that banks that induce reinforcement of management increase the probability of success. Due to high correlations among variables, the two other measures are included in regression (8). Both the additional collateral and the additional covenants, in combination with extra debt, affect survival positively.

\section{Discussion}


Our results suggest a complex picture of bank-firm relationships in situations of financial distress. In this discussion we first summarize our main findings. In addition we interpret these findings in relation to theory and the institutional setting.

Our first finding is that the ratio of debt to assets before restructuring is lower in successful firms than in unsuccessful firms. When we split up the debt we find that successful firms have less short-term debt and more interest-bearing and bank debt. Based on the latter result, it seems that banks owe less debt when failure is more likely. This implies that banks are well-informed about the overall debt ratio and choose to restrict their lending to indebted high-risk firms.

Our second finding concerns the measures taken. In both groups, many firms take operational measures and many firms effectuate measures that banks advise (or induce), together with bank debt related measures. Our analyses show that the measures in this latter category, however, make the difference between success and failure. From an operational perspective, the success of restructuring efforts depends crucially on operational measures that are induced by banks. This finding sheds an interesting light on the role of banks. Banks have a powerful say in the restructuring activities of firms. This power arises to the circumstance that they are knowledgeable concerning the state of affairs and are in a position to offer some debt relief and additional funds under conditions. Nevertheless, it is the firm's management that has to respond to this approach. In the case that firms are affirmative and are prepared to take corrective actions, banks are co-operative. Especially the fact that unsuccessful firms divest less, do less to reinforce management and do not accept additional restrictive covenants point in the direction that these firms have not been able to secure, or were not willing to accept the support of the bank. Even in financial distress situations "it takes two to tango".

Overall our conclusion is that the role of banks is crucial in discriminating between success and failure. On the one hand, banks screen firms and as a result they are less involved as creditors in the highly levered unsuccessful firms. On the other hand, banks help firms they are more involved in. There are two likely, and related, reasons for their involvement. First, banks have larger portions of debt in these firms. Second, these firms are less indebted and thus the measures taken are more likely to yield the desired results.

The major finding of this paper is that banks are not lazy in offering support to failing firms. Banks will not be overly generous, but they help by providing additional 
financing coupled with a tightening of the conditions. It can be considered as an intensification of the monitoring effort. The other side of the coin is that this support is only forthcoming when firms act on their predicament by starting to take their situation serious and contacting their bank.

Private renegotiations are promoted by harsh bankruptcy rules and by dispersed debt. In order for such renegotiation to be successful it will be extremely beneficial to have an active bank that may provide additional capital. With private renegotiation between debtor and bank, it is the group of dispersed trade creditors that free ride on the renegotiation results. As our data shows the private renegotiation phase can be rather lengthy. But if this restructuring process fails, firms are most likely not sufficiently viable. Firms have not been able to capitalize on the support of the bank in order to reorganize to be at least marginally profitable. It will become very hard for firms to start the process all over again. The implication is that firms that end up in bankruptcy will predominantly be sold in parts and/or liquidated. With little value left and most or all of the assets in security with banks, little remains for other creditors. So the other creditors win when private renegotiation succeeds and lose when it fails. In other bankruptcy systems, where soft bankruptcy rules prevail, an important part of the private activities are driven into bankruptcy. The main motivation for this may be that banks do not want to give in twice. Banks will become lazier, i.e. will not be as active as compared to a situation in which harsh bankruptcy rules are present. Furthermore, they will ask more concessions from other creditors, before they give in on their secured position. It means though that firms will enter a bankruptcy procedure sooner, generate higher pay-outs and will be monitored by an outside trustee. But it does not automatically mean that such a system is to be considered as more efficient as a harsh system. Most importantly, the benefits of private renegotiation are lost, i.e. lower costs and higher pay-outs for all creditors in successful firms.

\section{Conclusion}

This paper studies the restructuring process of small Dutch firms in financial distress. We obtained a unique dataset with firms that are assisted in their restructuring by 
banks, which includes all restructuring measures taken by the firm, the bank and other stakeholders. Our dataset consists of firms that successfully restructured and firms that did not succeed in reorganizing. We run empirical tests that aim to predict success and failure in restructuring. The main result is that banks are willing to assist firms in restructuring. We also find that this assistance is of crucial importance to the success of the restructuring. However, some firms do not benefit from this assistance. We conclude that firms do not fail in the case that they are prepared to undertake radical operational changes and bank assistance is forthcoming.

Our results have interesting implications about bankruptcy systems. The Dutch firms in our sample reorganize under harsh bankruptcy rules. The analysis shows that private reorganization occurs and that it crucially depends on bank involvement. Furthermore, trade creditors seem to fill in a role that is similar to widespread debt holders. With harsh bankruptcy rules these creditors free ride on the private involvement of banks. This is in contrast to soft systems where these debt holders have to give in first before senior/secured creditors give in. The efficiency of harsh systems thus depends on facilitating private reorganization. If such private reorganization in harsh systems fails then small firms do not have much of an ex post alternative to avoid bankruptcy. 


\section{References}

Asquith, Paul, Robert Gertner, and David Scharfstein, 1994, “Anatomy of financial distress: An examination of junk-bond issuers," Quarterly Journal of Economics 109, 625-658.

Berglof, Erik, and Ernst-Ludwig von Thadden, 1994, "Short-term versus long-term interests: Capital structure with multiple investors," Quarterly Journal of Economics 109, 1055-1084.

Berglof, Erik, Gerard Roland, and Ernst-Ludwig von Thadden, 1999, "Optimal capital structure and bankruptcy law,” Working Paper Stockholm School of Economics.

Bergstrom, Clas, Theodore Eisenberg, and Stefan Sundgren, 2002, "Secured debt and the likelihood of reorganization," International Review of Law and Economics 21, 359-372.

Bigus, Jochen, 2002, "Bankruptcy law, asset substitution problem and creditor conflicts," International Review of Law and Economics 22, 109-132.

Bolton, Patrick, and David S. Scharfstein, 1996, "Optimal debt structure and the number of creditors,” Journal of Political Economy 104, 1-25.

Bulow, Jeremy I., and John B. Shoven, 1978, "The bankruptcy decision,” The Bell Journal of Economics 9, 437-456.

Couwenberg, Oscar, 1997, Resolving financial distress in the Netherlands, Dissertation, University of Groningen.

Couwenberg, Oscar, 2001, "Survival rates in bankruptcy systems: Overlooking the evidence,” European Journal of Law and Economics 12, 253-273.

Couwenberg, Oscar, and Mark Helmantel, 2004, "The allocation of collateral to creditors,” Working Paper University of Groningen.

Diamond, Douglas W., 1984, "Financial intermediation and delegated monitoring," Review of Economic Studies LI, 393-414.

Diamond, Douglas W., 1993, "Bank loan maturity and priority when borrowers can refinance," in: Colin Mayer and Xavier Vives, Capital markets and financial intermediation, Cambridge University Press, 46-80.

Eisenberg, Theodore, and Shoichi Tagashira, 1994, "Should we abolish chapter 11 ? The evidence from Japan,“ Journal of Legal Studies XXIII, 111-157.

Franks, Julian R., Kjell G. Nyborg, and Walter N. Torous, 1996, “A comparison of US, UK, and German insolvency codes,” Financial Management 25, 86-101.

Franks, Julian R., and Oren Susmann, 2003, "Financial distress and bank restructuring of small-to-medium size UK enterprises,” CEPR Discussion Paper no 3915.

Franks, Julian R., and Walter N. Torous, 1994, "A comparison of financial recontracting in distressed exchanges and Chapter 11 reorganizations," Journal of Financial Economics 35, 349-370.

Franks, Julian R., and Walter N. Torous, 1996, "Lessons from a comparison of U.S. and U.K. insolvency codes,” in: Jagdeep S. Bhandari and Lawrence A. Weiss, Corporate bankruptcy: economic and legal perspectives, Cambridge University Press, 450-466.

Gertner, Robert, and David Scharfstein, 1991, "A theory of workouts and the effects of reorganization law,” The Journal of Finance 46, 1189-1222.

Gilson, Stuart C., 1990, "Bankruptcy, boards, banks, and blockholders," Journal of Financial Economics 27, 355-387.

Gilson, Stuart C., Kose John, and Larry H.P. Lang, 1990, “Troubled debt restructurings: An empirical study of private reorganization of firms in default,” Journal of Financial Economics 27, 315-353. 
Gorton, Gary, and James Kahn, 1993, “The design of bank loan contracts, collateral, and renegotiation,” NBER Working Paper no 4273.

Hart, Oliver, 1995, Firms, contracts and financial structure, Clarendon Press.

Hart, Oliver, and John Moore, 1998, "Default and renegotiation: A dynamic model of debt,” Quarterly Journal of Economics 113, 1-41.

Haubrich, Joseph G., 1989, "Financial intermediation, delegated monitoring and longterm relationships,” Journal of Banking and Finance 13, 9-20.

James, Christopher, 1995, "When do banks take equity in debt restructurings?," The Review of Financial Studies 8, 1209-1234.

John, Kose, and Gopala K. Vasudevan, 1995, "The role of banks in debt restructuring," in: Dilip K. Ghosh, New advances in financial economics, Pergamon Elsevier Science, 97-109.

Kaiser, Kevin M.J., 1996, "European bankruptcy laws: Implications for corporations facing financial distress,” Financial Management 25, 67-85.

Manove, Michael, A. Jorge Padilla, and Marco Pagano, 2001, "Collateral versus project screening: A model of lazy banks," Rand Journal of Economics 32, 726744.

Myers, Stewart C., 1977, "Determinants of corporate borrowing," Journal of Financial Economics 5, 147-175.

Ravid, S. Abraham, and Stephan Sundgren, 1998, "The Comparative Efficiency of Small-firm Bankruptcies: A Study of the US and the Finnish Bankruptcy Codes.” Financial Management 27, 28-40.

Sundgren, Stephan, 1998, "Does a Reorganization Law Improve the Efficiency of the Insolvency Law? The Finnish Experience," European Journal of Law and Economics 6, 177-198.

Tashijan, Elizabeth, Ronald C. Lease, and John J. McConnell, 1996, "Prepacks, an empirical analysis of prepackaged bankruptcies," Journal of Financial Economics 40, 135-162.

Thorburn, Karin S., 1999, "Bankruptcy auctions: Costs, debt recovery, and firm survival,” Journal of Financial Economics 58, 337-368.

Udell, Gregory F., 1989, "Loan quality, commercial loan review and loan officer contracting," Journal of Banking and Finance 13, 367-382.

Welch, Ivo, 1997, "Why is bank debt senior? A theory of asymmetry and claim priority based on influence costs," The Review of Financial Studies 10, 1203-1236.

White, Michelle, 1980, "Public policy toward bankruptcy: Me-first and other priority rules,” The Bell Journal of Economics 11, 550-564.

White, Michelle, 1996, "The costs of corporate bankruptcy: A U.S.-European comparison,” in: Jagdeep S. Bhandari and Lawrence A. Weiss, Corporate bankruptcy: economic and legal perspectives, Cambridge University Press, 467500 . 
Table 1: Samples of successful and unsuccessful restructurings

This tables reports for 51 successful and 22 unsuccessful firms, size and industry distributions, the frequencies of reasons for distress and the outcomes of the restructurings. We report frequencies and the percentages of observations in a class.

\begin{tabular}{|c|c|c|c|c|}
\hline & \multicolumn{2}{|c|}{ Successful firms } & \multicolumn{2}{|c|}{ Unsuccessful firms } \\
\hline \multicolumn{5}{|c|}{ A: Total assets (x NLG 1000) } \\
\hline $\begin{array}{l}0-1000 \\
1000-5000 \\
5000-10000 \\
>10000\end{array}$ & $\begin{array}{c}0 \\
9 \\
9 \\
33\end{array}$ & $\begin{array}{c}0 \% \\
18 \% \\
18 \% \\
65 \%\end{array}$ & $\begin{array}{l}2 \\
5 \\
6 \\
9\end{array}$ & $\begin{array}{c}9 \% \\
23 \% \\
27 \% \\
41 \%\end{array}$ \\
\hline \multicolumn{5}{|c|}{ B: Industry } \\
\hline $\begin{array}{l}\text { Agriculture and construction } \\
\text { Manufacturing } \\
\text { Trade } \\
\text { Services and transport } \\
\text { Other/unknown } \\
\end{array}$ & $\begin{array}{c}4 \\
16 \\
14 \\
14 \\
3\end{array}$ & $\begin{array}{c}8 \% \\
31 \% \\
27 \% \\
27 \% \\
6 \% \\
\end{array}$ & $\begin{array}{c}1 \\
17 \\
3 \\
1 \\
0 \\
\end{array}$ & $\begin{array}{c}5 \% \\
77 \% \\
14 \% \\
5 \% \\
0 \% \\
\end{array}$ \\
\hline \multicolumn{5}{|c|}{ C: Reasons of distress } \\
\hline $\begin{array}{l}\text { Market forces } \\
\text { Cost level } \\
\text { Restrictive contracts } \\
\text { Overinvestment } \\
\text { Underinvestment } \\
\text { Excess financing } \\
\text { Weak management } \\
\text { Other }\end{array}$ & $\begin{array}{c}30 \\
29 \\
3 \\
24 \\
7 \\
6 \\
23 \\
23\end{array}$ & $\begin{array}{c}59 \% \\
57 \% \\
6 \% \\
47 \% \\
14 \% \\
12 \% \\
45 \% \\
45 \%\end{array}$ & $\begin{array}{c}13 \\
12 \\
1 \\
5 \\
4 \\
2 \\
11 \\
6\end{array}$ & $\begin{array}{c}59 \% \\
55 \% \\
5 \% \\
23 \% \\
18 \% \\
9 \% \\
50 \% \\
27 \%\end{array}$ \\
\hline \multicolumn{5}{|c|}{ D: Final outcome of restructuring } \\
\hline $\begin{array}{l}\text { Restructured } \\
\text { Not restructured } \\
\text { Repayment through new financier } \\
\text { Taken over } \\
\text { Going-concern sale } \\
\text { Piece-meal liquidation } \\
\text { Composition }\end{array}$ & $\begin{array}{c}19 \\
2 \\
17 \\
13 \\
- \\
- \\
-\end{array}$ & $\begin{array}{c}37 \% \\
4 \% \\
33 \% \\
25 \% \\
- \\
- \\
-\end{array}$ & $\begin{array}{l}- \\
- \\
- \\
- \\
14 \\
7 \\
1\end{array}$ & $\begin{array}{c}- \\
- \\
- \\
- \\
64 \% \\
32 \% \\
5 \%\end{array}$ \\
\hline
\end{tabular}




\section{Table 2: Firm characteristics}

This tables reports firm characteristics for 51 successful and 22 unsuccessful firms. The definitions are in the first column. The second and fourth columns have the average values and the third and fifth column report the number of observations per variable. The final column has the difference in mean and the $t$-value of a test for the difference in means. ' $* * *$ ' denotes significance at the $1 \%$ level, ' $* *$ ' at the $5 \%$ level and '*' at the $10 \%$ level.

\begin{tabular}{|l|c|c|c|c|ll|}
\hline & \multicolumn{2}{|c|}{$\begin{array}{c}\text { Successful } \\
\text { firms }\end{array}$} & \multicolumn{2}{c|}{$\begin{array}{c}\text { Unsuccessful } \\
\text { firms }\end{array}$} & \multicolumn{2}{l|}{ Difference (t-value) } \\
\hline Total assets (x NLG 1000) & 25442 & 51 & 14346 & 22 & 11096 & $(1.60)$ \\
Total debt/total assets & 0.896 & 51 & 1.343 & 22 & -0.447 & $(-4.54)^{* * *}$ \\
Short-term debt/total debt & 0.360 & 51 & 0.510 & 21 & -0.150 & $(-2.89)^{* * *}$ \\
Interest-bearing debt/total debt & 0.649 & 51 & 0.541 & 21 & 0.108 & $(2.13)^{* *}$ \\
Bank debt/total debt & 0.551 & 51 & 0.398 & 20 & 0.152 & $(2.84)^{* * *}$ \\
Number of collaterals & 2.98 & 51 & 3.00 & 22 & -0.02 & $(-0.08)$ \\
Collateral value/bank debt & 2.046 & 51 & 2.338 & 20 & -0.292 & $(-0.83)$ \\
Average length in months & 24.57 & 51 & 23.63 & 20 & 0.89 & $(0.14)$ \\
\hline
\end{tabular}




\section{Table 3: Restructuring measures}

This tables reports restructuring measures taken by 51 successful and 22 unsuccessful firms. The definitions are in the first column. The second and third column reports the percentages of firms that choose a measure. The final column has the $p$-value of a difference test. ' $* * *$ ' denotes significance at the $1 \%$ level, '**' at the $5 \%$ level and '*' at the $10 \%$ level.

\begin{tabular}{|c|c|c|c|}
\hline & $\begin{array}{l}\text { Successful } \\
\text { firms }\end{array}$ & $\begin{array}{l}\text { Unsuccessful } \\
\text { firms }\end{array}$ & $\begin{array}{c}p \text {-value } \\
\text { difference }\end{array}$ \\
\hline \multicolumn{4}{|c|}{ A: Role of shareholders in financing } \\
\hline $\begin{array}{l}\text { Additional equity } \\
\text { Junior debt } \\
\text { Debt without collateral } \\
\text { Total }\end{array}$ & $\begin{array}{c}3.9 \% \\
15.7 \% \\
2.0 \% \\
19.6 \% \\
\end{array}$ & $\begin{array}{c}13.6 \% \\
18.2 \% \\
4.5 \% \\
22.7 \% \\
\end{array}$ & $\begin{array}{l}0.14 \\
0.80 \\
0.54 \\
0.77\end{array}$ \\
\hline \multicolumn{4}{|c|}{ B: Role of banks } \\
\hline $\begin{array}{l}\text { Extension repayment principal } \\
\text { Extension interest payments } \\
\text { Reduction interest rate } \\
\text { Debt write down } \\
\text { Ease credit conditions } \\
\text { Hasten repayment principal } \\
\text { Additional collateral } \\
\text { Additional debt under conditions: } \\
\text { - Fresh equity or junior debt } \\
\text { - Additional collateral } \\
\text { - Additional restrictive covenants } \\
\text { - Extra information } \\
\text { - Divestment } \\
\text { - Reinforcement of management } \\
\text { Total }\end{array}$ & $\begin{array}{c}33.3 \% \\
2.0 \% \\
0 \% \\
0 \% \\
3.9 \% \\
33.3 \% \\
43.1 \% \\
58.8 \% \\
13.7 \% \\
45.1 \% \\
76.5 \% \\
56.9 \% \\
37.3 \% \\
31.4 \% \\
90.2 \%\end{array}$ & $\begin{array}{c}22.7 \% \\
0 \% \\
0 \% \\
0 \% \\
0 \% \\
18.2 \% \\
4.5 \% \\
59.1 \% \\
22.7 \% \\
36.4 \% \\
31.8 \% \\
27.3 \% \\
4.5 \% \\
9.1 \% \\
59.1 \%\end{array}$ & $\begin{array}{c}0.37 \\
0.52 \\
- \\
- \\
0.35 \\
0.20 \\
<0.01^{* * *} \\
0.98 \\
0.35 \\
0.49 \\
<0.01^{* * *} \\
0.02^{* *} \\
<0.01^{* * *} \\
0.04^{* *} \\
<0.01^{* * *}\end{array}$ \\
\hline \multicolumn{4}{|c|}{$C:$ Role of other creditors in financing } \\
\hline $\begin{array}{l}\text { Extension principal/interest payments } \\
\text { Additional funds } \\
\text { Additional collateral } \\
\text { Hasten repayment of principal } \\
\text { Additional restrictive conditions } \\
\text { Additional extension of trade credit } \\
\text { Total }\end{array}$ & $\begin{array}{c}9.8 \% \\
21.6 \% \\
11.8 \% \\
7.8 \% \\
2.0 \% \\
17.6 \% \\
39.2 \%\end{array}$ & $\begin{array}{c}13.6 \% \\
27.3 \% \\
9.1 \% \\
0 \% \\
0 \% \\
18.2 \% \\
50.0 \%\end{array}$ & $\begin{array}{l}0.64 \\
0.60 \\
0.74 \\
0.18 \\
0.52 \\
0.96 \\
0.40\end{array}$ \\
\hline
\end{tabular}


Table 3 (continued): Restructuring measures

\begin{tabular}{|c|c|c|c|}
\hline & $\begin{array}{l}\text { Successful } \\
\text { firms }\end{array}$ & $\begin{array}{l}\text { Unsuccessful } \\
\text { firms }\end{array}$ & Difference \\
\hline \multicolumn{4}{|c|}{ D: Operational measures } \\
\hline Strategy & $25.5 \%$ & $18.2 \%$ & 0.51 \\
\hline Purchase & $2.0 \%$ & $4.5 \%$ & 0.54 \\
\hline Production & $29.4 \%$ & $27.3 \%$ & 0.86 \\
\hline Sales & $7.8 \%$ & $9.1 \%$ & 0.86 \\
\hline Financial control & $17.6 \%$ & $22.7 \%$ & 0.62 \\
\hline Sell assets & $56.9 \%$ & $9.1 \%$ & $<0.01 * * *$ \\
\hline Acquisitions & $15.7 \%$ & $4.5 \%$ & 0.19 \\
\hline Adjustment organization & $7.8 \%$ & $9.1 \%$ & 0.86 \\
\hline Adjust legal structure & $13.7 \%$ & $18.2 \%$ & 0.63 \\
\hline Rescue via take over & $29.4 \%$ & $27.3 \%$ & 0.86 \\
\hline Reduction work force & $25.5 \%$ & $27.3 \%$ & 0.88 \\
\hline Total & $86.3 \%$ & $50.0 \%$ & $<0.01 * * *$ \\
\hline \multicolumn{4}{|c|}{ E: Role of shareholders in governance } \\
\hline Interim management & $3.9 \%$ & $0 \%$ & 0.35 \\
\hline Fire management & $15.7 \%$ & $4.5 \%$ & 0.19 \\
\hline Replace management & $11.8 \%$ & $0 \%$ & $0.09 *$ \\
\hline External management & $9.8 \%$ & $0 \%$ & 0.13 \\
\hline Rescue attempt via take over & $13.7 \%$ & $4.5 \%$ & 0.26 \\
\hline Total & $51.0 \%$ & $27.3 \%$ & $0.06 *$ \\
\hline \multicolumn{4}{|c|}{$F:$ Role of board in governance } \\
\hline Interim management & $7.8 \%$ & $4.5 \%$ & 0.62 \\
\hline Fire management & $7.8 \%$ & $9.1 \%$ & 0.86 \\
\hline Replace management & $3.9 \%$ & $0 \%$ & 0.35 \\
\hline External management & $9.8 \%$ & $4.5 \%$ & 0.46 \\
\hline Rescue attempt via take over & $2.0 \%$ & $0 \%$ & 0.52 \\
\hline Total & $17.6 \%$ & $18.2 \%$ & 0.96 \\
\hline \multicolumn{4}{|c|}{ G: Role of management in governance } \\
\hline Management fired & $15.7 \%$ & $18.2 \%$ & 0.80 \\
\hline Total & $15.7 \%$ & $18.2 \%$ & 0.80 \\
\hline \multicolumn{4}{|c|}{ H: Summary } \\
\hline Average number of measures & 8.84 & 6.09 & $0.04 * *$ \\
\hline Average fraction of measures & 0.201 & 0.138 & $0.04 * *$ \\
\hline
\end{tabular}




\section{Table 4: Logit regression predicting success}

This table reports the results of logit regression models that explain success in restructuring for a sample of 51 successful and 22 unsuccessful firms. We report the logit regression coefficients and $z$ statistics in parentheses. The McFadden $R^{2}$ indicates the explanatory power of the model. The variables are in the first column and these variables are defined in Tables 2 and 3. '***' denotes significance at the $1 \%$ level, '**' at the $5 \%$ level and '*' at the $10 \%$ level.

\begin{tabular}{|c|c|c|c|c|}
\hline \multicolumn{5}{|c|}{ A: Firm characteristics } \\
\hline & (1) & (2) & (3) & (4) \\
\hline Intercept & $\begin{array}{c}0.601 \\
(0.19)\end{array}$ & $\begin{array}{l}-3.104 \\
(-1.08)\end{array}$ & $\begin{array}{c}-5.047^{*} \\
(-1.65)\end{array}$ & $\begin{array}{l}-5.321 \\
(-1.49)\end{array}$ \\
\hline Log (Total assets) & $\begin{array}{l}0.472 \\
(1.52)\end{array}$ & $\begin{array}{c}0.713 * * \\
(2.32)\end{array}$ & $\begin{array}{c}0.681^{* *} \\
(2.33)\end{array}$ & $\begin{array}{c}0.672^{* *} \\
(2.11)\end{array}$ \\
\hline Dummy Manufacturing & $\begin{array}{l}-2.089 * \\
(-1.72)\end{array}$ & $\begin{array}{l}-2.217^{*} \\
(-1.77)\end{array}$ & $\begin{array}{c}-2.257 * \\
(-1.86)\end{array}$ & $\begin{array}{l}-1.950 \\
(-1.58)\end{array}$ \\
\hline Dummy Trade & $\begin{array}{l}-0.307 \\
(-0.22)\end{array}$ & $\begin{array}{l}-0.794 \\
(-0.59)\end{array}$ & $\begin{array}{l}-0.717 \\
(-0.55)\end{array}$ & $\begin{array}{l}-0.698 \\
(-0.52)\end{array}$ \\
\hline Dummy Service and Transport & $\begin{array}{c}0.945 \\
(0.59)\end{array}$ & $\begin{array}{l}0.245 \\
(0.15)\end{array}$ & $\begin{array}{l}0.380 \\
(0.24)\end{array}$ & $\begin{array}{l}0.420 \\
(0.27)\end{array}$ \\
\hline Total debt/total assets & $\begin{array}{c}-2.878 * * * \\
(-2.73)\end{array}$ & & & \\
\hline Short-term debt/total debt & & $\begin{array}{l}-3.102 * \\
(-1.80)\end{array}$ & & \\
\hline Interest-bearing debt/total debt & & & $\begin{array}{l}1.538 \\
(0.88)\end{array}$ & \\
\hline Bank debt/total debt & & & & $\begin{array}{l}3.046^{*} \\
(1.78)\end{array}$ \\
\hline Number of collaterals & & & & $\begin{array}{l}0.026 \\
(0.11)\end{array}$ \\
\hline Collateral value/bank debt & & & & $\begin{array}{l}-0.136 \\
(-0.39) \\
\end{array}$ \\
\hline McFadden $R^{2}$ & 0.351 & 0.281 & 0.239 & 0.252 \\
\hline Observations & 73 & 73 & 72 & 71 \\
\hline
\end{tabular}


Table 4 (continued): Logit regression predicting success

\begin{tabular}{|c|c|c|c|c|}
\hline \multicolumn{5}{|c|}{ B: Restructuring characteristics } \\
\hline & (5) & (6) & (7) & (8) \\
\hline Intercept & $\begin{array}{l}0.394 \\
(0.12)\end{array}$ & $\begin{array}{l}-2.255 \\
(-0.53)\end{array}$ & $\begin{array}{l}2.555 \\
(0.55)\end{array}$ & $\begin{array}{l}-0.086 \\
(-0.02)\end{array}$ \\
\hline Log (Total assets) & $\begin{array}{l}0.437 \\
(1.35)\end{array}$ & $\begin{array}{l}0.816^{*} \\
(1.71)\end{array}$ & $\begin{array}{l}0.357 \\
(0.88)\end{array}$ & $\begin{array}{l}0.481 \\
(1.19)\end{array}$ \\
\hline Dummy Manufacturing & $\begin{array}{l}-2.03^{*} \\
(-1.67)\end{array}$ & $\begin{array}{c}-3.821 * \\
(-1.94)\end{array}$ & $\begin{array}{l}-1.122 \\
(-0.72)\end{array}$ & $\begin{array}{c}-3.559 * * \\
(-2.28)\end{array}$ \\
\hline Dummy Trade & $\begin{array}{l}-0.248 \\
(-0.18)\end{array}$ & $\begin{array}{l}-2.599 \\
(-1.26)\end{array}$ & $\begin{array}{l}0.675 \\
(0.40)\end{array}$ & $\begin{array}{l}-1.173 \\
(-0.71)\end{array}$ \\
\hline Dummy Service and Transport & $\begin{array}{l}1.036 \\
(0.64)\end{array}$ & $\begin{array}{l}-0.130 \\
(-0.06)\end{array}$ & $\begin{array}{l}0.900 \\
(0.45)\end{array}$ & $\begin{array}{l}0.335 \\
(0.19)\end{array}$ \\
\hline Total debt/total assets & $\begin{array}{c}-3.019 * * * \\
(-2.74)\end{array}$ & $\begin{array}{l}-3.29 * * \\
(-2.33)\end{array}$ & $\begin{array}{c}-5.877 * * * \\
(-2.93)\end{array}$ & $\begin{array}{c}-3.157^{* *} \\
(-2.35)\end{array}$ \\
\hline Fraction of measures & $\begin{array}{l}3.376 \\
(1.14)\end{array}$ & & & \\
\hline Shareholders/financing & & $\begin{array}{l}-1.167 \\
(-1.31)\end{array}$ & & \\
\hline Bank & & $\begin{array}{l}0.911 * * * \\
(2.70)\end{array}$ & & \\
\hline Other creditors & & $\begin{array}{c}-1.590^{* *} \\
(-2.24)\end{array}$ & & \\
\hline Operational & & $\begin{array}{l}-0.003 \\
(-0.01)\end{array}$ & & \\
\hline Shareholders/governance & & $\begin{array}{l}1.419 \\
(1.37)\end{array}$ & & \\
\hline Board/governance & & $\begin{array}{l}0.272 \\
(0.29)\end{array}$ & & \\
\hline Management/governance & & $\begin{array}{l}-2.050 \\
(-1.30)\end{array}$ & & \\
\hline Bank: divestment & & & $\begin{array}{c}6.179 * * \\
(2.51)\end{array}$ & \\
\hline $\begin{array}{l}\text { Operational: sell assets } \\
\text { (-Bank: divestment) }\end{array}$ & & & $\begin{array}{l}1.689 \\
(1.51)\end{array}$ & \\
\hline Bank: management & & & $\begin{array}{l}2.51 * \\
(1.84)\end{array}$ & \\
\hline Bank: additional collateral & & & & $\begin{array}{c}2.456^{*} \\
(1.92)\end{array}$ \\
\hline Bank: additional terms & & & & $\begin{array}{c}2.634 * * * \\
(2.75)\end{array}$ \\
\hline McFadden $R^{2}$ & 0.369 & 0.559 & 0.554 & 0.557 \\
\hline Observations & 73 & 73 & 73 & 73 \\
\hline
\end{tabular}




\section{Publications in the Report Series Research* in Management}

\section{ERIM Research Program: "Finance and Accounting"}

2004

Corporate Finance In Europe Confronting Theory With Practice

Dirk Brounen, Abe de Jong and Kees Koedijk

ERS-2004-002-F\&A

http://hdl.handle.net/1765/1111

Downside Risk And Asset Pricing

Thierry Post and Pim van Vliet

ERS-2004-018-F\&A

http://hdl.handle.net/1765/1424

An Alternative Decomposition Of The Fisher Index

Winfried G. Hallerbach

ERS-2004-022-F\&A

http://hdl.handle.net/1765/1220

A Gmm Test For Ssd Efficiency

Thierry Post And Philippe Versijp

ERS-2004-024-0F\&A

http://hdl.handle.net/1765/1426

Purchasing Power Parity and the Euro Area

Kees G. Koedijk, Ben Tims and Mathijs A. van Dijk

ERS-2004-025-F\&A

http://hdl.handle.net/1765/1442

The effects of systemic crises when investors can be crisis ignorant

Erik Kole, Kees Koedijk \& Marno Verbeek

ERS-2004-027-F\&A

http://hdl.handle.net/1765/1270

The Eco-Efficiency Premium Puzzle

Jeroen Derwall, Nadja Günster, Rob Bauer and Kees Koedijk

ERS-2004-043-F\&A

http://hdl.handle.net/1765/1296

Shareholders' Voting at General Meetings: Evidence from the Netherlands

Abe De Jong, Gerard Mertens And Peter Roosenboom

ERS-2004-039-F\&A

http://hdl.handle.net/1765/1332

\footnotetext{
* A complete overview of the ERIM Report Series Research in Management: https://ep.eur.nl/handle/1765/1

ERIM Research Programs:

LIS Business Processes, Logistics and Information Systems

ORG Organizing for Performance

MKT Marketing

F\&A Finance and Accounting

STR Strategy and Entrepreneurship
} 
Do banks influence the capital structure choices of firms?

Petra Daniševská, Abe de Jong \& Marno Verbeek

ERS-2004-040-F\&A

http://hdl.handle.net/1765/1333

Conditional Downside Risk and the CAPM

Thierry Post And Pim Van Vliet

ERS-2004-048-F\&A

http://hdl.handle.net/1765/1425

It Takes Two To Tango: An Empirical Tale Of Distressed Firms And Assisting Banks Oscar Couwenberg and Abe de Jong

ERS-2004-049-F\&A 